\title{
Hemşirelik Öğrencilerinin Bireysel Yenilikçilik Davranışları ile Otonomi Düzeyleri Arasındaki İlişski
}

\section{The Relationship between Nursing Students' Individual Innovative Behaviors and Autonomy Levels}

\begin{abstract}
Merve TARHAN ${ }^{\mathrm{a}}$ Pınar DOĞAN ${ }^{\mathrm{b}}$
ÖZ Amaç: Geleceğin hemşirelerine sürekli değişen ve gelişen dünya düzeni içinde mesleğin varlığını koruyabilecek ve sürdürebilecek nitelikleri kazandırmak son derece önemlidir. Bu fikirden yola çıkılarak gerçekleştirilen çalışmada, hemşirelik öğrencilerinin bireysel yenilikçilik davranışları ile otonomi düzeyleri arasındaki ilişkinin belirlenmesi amaçlandı. Gereç ve Yöntemler: Tanımlayıcı-ilişki arayıcı nitelikteki çalışma, İstanbul'da bir vakıf üniversitesinin hemşirelik bölümünde öğrenim gören 283 öğrenci ile gerçekleştirildi. Bireysel Bilgi Formu, Bireysel Yenilikçilik Ölçeği ve Sosyotropi-Otonomi ölçeğinin alt boyutu Otonomi Ölçeği’nden oluşan anket formu ile veriler toplandı. Tanımlayıcı testler, Mann Whitney- U testi, Kruskal Wallis analizi ve Spearman korelasyon analizi kullanılarak veriler değerlendirildi. Bulgular: Öğrencilerin Bireysel Yenilikçilik Ölçeği'den aldıkları puan ortalamasının $65.26 \pm 8.66$ ve Otonomi Ölçeğinden aldıkları puan ortalamasının $81.23 \pm 18.18$ olduğu belirlendi. Öğrencilerin \%36,4'ünün kuşkucu yenilikçi davranışı kategorisinde yer aldığı saptandı. Bireysel Yenilikçilik Ölçeği ile Otonomi Ölçeği arasında pozitif yönde zayıf ilişsi saptandı $(\mathrm{r}=0.26$; $\mathrm{p}<0.001)$. Yenilikçi kategorisinde bulunan öğrencilerin Otonomi Ölçeği’den aldıkları sıra ortalaması, diğer kategorilerdeki öğrencilerden ileri düzeyde anlamlı derecede yüksek bulundu $(\mathrm{p}<0.001)$. Sonuç: Çalışmanın sonuçları, öğrencilerin bireysel yenilikçilik davranışları ve otonomi düzeylerinin orta düzeyde yüksek olduğunu, birbirleri arasında pozitif bir ilişki bulunduğunu ve yenilikçi kategorisinde bulunan öğrencilerin otonomi düzeylerinin daha yüksek olduğunu göstermektedir. Hemşirelik eğitim programlarının, öğrencilerin bireysel yenilikçilik davranışları ve otonomi düzeylerini geliştirecek yönde zenginleştirilmesi önerilmektedir.
\end{abstract}

Anahtar Kelimeler: Bireysel yenilikçilik davranışı, hemşirelik öğrencileri, otonomi

\begin{abstract}
Objective: It is extremely important to provide qualifications that can protect and sustain the existence of profession to the nurses of the future in constantly changing and developing world order. From this point of view, the study was conducted to determine the relationship between individual innovative behavior and autonomy levels. Methods: The descriptive-correlational study was carried out with 283 students studying in nursing department of a Foundation University in Istanbul. The data was collected with the questionnaire form consisted of Individual Information Form, Individual Innovative Scale and the autonomy sub dimension of Sociotropy-Autonomy Scale. The data was evaluated with using descriptive tests, Mann Whitney-U testi, Kruskal Wallis analysis and Spearman correlation analysis. Results: It was determined that the mean score of the students

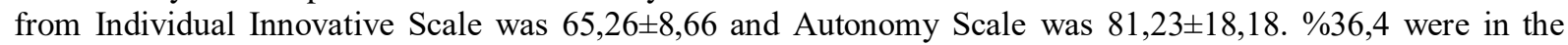
category of late majority innovative behavior. It was determined that there was weak and significant positive correlation between Individual Innovative Behavior and Autonomy Scale $(r=0,26 ; p<0,001)$. The mean rank of the students in the innovative category was significantly higher at advanced level than the students of other categories $(p<0,001)$. Conclusion: The results of study shows that the individual innovative behavior and autonomy levels of the students were moderately high, there was a positive relationship between the two and the autonomy levels of students in the innovative category was higher. It is suggested that nursing curriculum should be enriched in the way that students develop individual innovative behaviors and autonomy levels.
\end{abstract}

Keywords: Individual innovative behavior, nursing students, autonomy

\section{Giriș}

Sağlık bakım teknolojilerindeki ilerlemeler, yüksek kalitede sağlı hizmeti sunma çabaları ve toplumun farklılaşan ihtiyaç ve beklentileri

karşısında eski olanı değiştirebilen, yeni olanı uygulayabilen ve yenilikçi yaklaşımlar üretebilen hemşireler yetiştirmek, mesleğin

Geliș Tarihi/Received: 26-09-2017/ Kabul Tarihi/Accepted:14-11-2017

a Öğr. Gör. İstanbul Medipol Üniversitesi Sağlık Bilimleri Fakültesi Hemşirelik Bölümü, Kavacık mah. Ekinciler cad. No:19 Kavacık Kavşağı 34810 Beykoz/ISTANBUL, e-mail:mtarhan@medipol.edu.tr, ORCID:0000-0002-9841-4708

b İstanbul Medipol Üniversitesi Sağlık Bilimleri Fakültesi Hemşirelik Bölümü Kavacık mah. Ekinciler cad. No:19 Kavacık Kavşağı 34810 Beykoz/ISTANBUL, e-mail:pdogan@medipol.edu.tr, ORCID:0000-0002-3566-7070

Sorumlu Yazar /Correspondence: Öğr. Gör. Merve TARHAN, İstanbul Medipol Üniversitesi Sağlık Bilimleri Fakültesi Hemşirelik Bölümü, e-mail: mtarhan@medipol.edu.tr

12-13 Mayıs 2016 tarihleri arasında gerçekleştirilen İstanbul Aydın Üniversitesi I. İstanbul Disiplinlerarası Sağlık Bilimleri Öğrenci Araştırmaları Kongresi'nde sözlü olarak sunulmuştur. 
varlığını korumak ve sürdürebilmek için önemli ve zorunludur. ${ }^{1-3}$ Hemşirelikte yenilikçilik, bireylerin ihtiyaçlarını karşılamak, bakım maliyetlerini azaltmak ve iş verimliliğini arttırmak için yeni fikirlerin, tekniklerin ya da prosedürlerin uygulanmas1 olarak tanımlanmaktadır. ${ }^{4}$ Hemşirelikte yenilikçilik davranışını geliştirmenin bakım kalitesini, iş üretkenliğini ve tedavinin etkinliğini arttırdığını, sağlık bakım maliyetlerini azalttığını ve sağlık hizmetlerine ulaşımı kolaylaştırdığını gösteren çalışmalar mevcuttur. $^{4-6} \mathrm{Bu}$ davranışını etkileyen mesleki, örgütsel ve çevresel etmenlerin yanı sıra bireysel etmenler de bulunmaktadır. ${ }^{3}$ İnsanın özgür düşünüp karar verme yetisini eyleme geçirme ve bağımsız davranma gücü olan otonomi, bireysel etmenler arasinda en önemlisi olarak karşımıza çıkmaktadır. ${ }^{7-9}$ Çalışanın işe ilişkin yeni fikirler üretmesinde, yeni ürün ve yöntemler geliştirmesinde ve kullanmasında, özgürlük duygusu ve otonominin önemli olduğu belirtilmektedir. ${ }^{7}$

Literatürde, hemşirelerin ve hemşirelik dışı üniversite öğrencilerinin yenilikçilik davranışlarını belirleyen ve bu davranışların farklı değişkenlerle ilişkisini gösteren çalışmalar bulunmasına rağmen, hemşirelik öğrencilerine yönelik yapılmış herhangi bir çalışmaya rastlanmamıştır. $\mathrm{Bu}$ sebeple çalışmanın önemli olduğu ve hemşirelik öğrencilerinin yenilikçi davranışları ve otonomilerini arttıracak yenilikçi stratejiler konusunda hemşire eğitimcilere ve yöneticilere ipuçları vereceği düşünülmektedir. Tüm bilgiler ışığında çalışma, hemşirelik öğrencilerinin bireysel yenilikçilik davranışları ile otonomi düzeyleri arasındaki ilişkinin belirlenmesi amacıyla gerçekleştirildi.

\section{Gereç ve Yöntemler}

\section{Araştırmanın Türü, Yeri-Zamanı ve Evren-Örneklemi}

Tanımlayıcı-ilişki arayıcı nitelikteki çalışma, bir vakıf üniversitesinin hemşirelik bölümünde öğrenim görmekte olan öğrenciler ile 1-30 Nisan 2016 tarihleri arasinda gerçekleştirildi. Çalışmanın evrenini belirtilen tarih aralığında bölümde öğrenim gören 419 öğrenci; örneklemini ise çalışmaya katılmayı kabul eden, çalışmanın yapıldığı tarih aralığında okulda bulunan ve anket formunu tam ve eksiksiz dolduran 283 öğrenci oluşturdu. Çalışmaya katılım oranı \%67,5 olarak bulundu.

\section{Veri Toplama Araçları}

Verilerin toplanmasında Bireysel Bilgi Formu, Bireysel Yenilikçilik Ölçeği ve Otonomi Ölçeği olmak üzere üç bölümden oluşan anket formu kullanıldı.

Bireysel Bilgi Formu: İlk bölüm 10 sorudan oluşmaktadır. Öğrencilerin yaş, cinsiyet, öğrenim düzeyi, hemşireliği tercih etme sebepleri ve lisans eğitimi sonras1 uzmanlaşma düşüncelerine yönelik 5 bireysel özelliği sorgulanmaktadır. Aynı zamanda bu bölümde, öğrencilerin hemşirelik bakımı konusundaki yenilikleri takip etme durumu, yenilikleri takip ettikleri bilgi kaynakları, lisans eğitimi programlarının kendilerine, bakım verme, otonomi ve yenilikçilik yeterliliği kazandırması konusundaki bireysel görüşlerini sorgulayan 5 soru yer almaktadır.

Bireysel Yenilikçilik Ölçeği (BYÖ): İkinci bölümde, bireylerin yenilikçilik davranışlarını değerlendirebilmek amaciyla 'Bireysel Yenilikçilik Ölçeği”, kullanıldı. Hurt ve arkadaşları (1977) tarafindan geliştirilen ölçeğin, Türkçe geçerlik ve güvenilirliği 2014 yılında Ayşegül Sarığlu tarafından 'Bireysel Yenilikçilik Ölçeğinin Hemşirelikte Geçerlik ve Güvenirliği'" adlı yüksek lisans tez çalışmasında yapılmıştır. 7'si fikir önderliği, 7'si değişime direnç ve 4'ü risk alma olmak üzere 18 madde ve 3 alt boyuttan oluşan ölçek 5'li Likert şeklinde yanıtlanmaktadır. Ölçek maddelerinin 11'i pozitif $(1-8,10,11,14,16$, 17), 7'si $(5,6,912,13,15,18)$ negatiftir. Bireysel yenilikçilik puan, pozitif maddelerden alınan toplam puandan, negatif maddelerden alınan toplam puanın çıkarılıp, elde edilen puana 42 eklenmesiyle hesaplanmaktadır. Ölçekten en düşük 18, en yüksek 90 puan alınabilmektedir. Elde edilen puanlara göre bireysel yenilikçilik davranışları sinıflandırılmaktadır. Elde edilen toplam puan, 82'nin üzerinde ise 'yenilikçi', 75-82 arasinda ise "öncü", 66-74 arasında ise "'sorgulayıcı", 58-64 arasında ise "'kuşkucu" ve 57'nin altında ise "' gelenekçi" olarak değerlendirilmektedir. ${ }^{10}$ Ölçeğin Croanbach's alfa değeri 0,82 olup, bizim çalışmamızda 0,72 olarak bulundu. 
Otonomi Ölçeği (OÖ): Üçüncü bölümde, bağımsız ve özerk kişilik özelliklerini ölçen Sosyotropi-Otonomi Ölçeği'nin otonomi alt boyutu kullanıldı. Beck ve arkadaşları (1983) tarafindan geliştirilen ölçeğin, Türkçe geçerlik ve güvenilirliği Şahin ve arkadaşları (1993) tarafından yapılmıştır. Otonomi Ölçeği 12 madde kişisel başarı, 12 madde özgürlük ve 6 madde yalnızlıktan hoşlanma olmak üzere 30 madde ve 3 alt boyuttan oluşmaktadır. Her madde 0: Hiç tanımlamıyor, 1: Biraz tanımlıyor, 2: Oldukça tanımlıyor, 3: İyi tanımlıyor, 4: çok iyi tanımlıyor şeklinde yanıtlanmaktadır. Ölçekten en düşük 0 , en yüksek 120 puan alınabilmektedir. Alınan puanın yüksek olması, otonomi düzeyinin yüksek olduğunu göstermektedir. ${ }^{11}$ Ölçeğin Croanbach's alfa değeri 0.81 olup, bizim çalışmamızda 0.90 olarak bulundu.

\section{Araştırmanın Etik Yönü}

Çalışmaya başlamadan önce İstanbul Medipol Üniversitesi Etik Kurulu'ndan etik onay (Karar No: 2016/367) ve kurumdan yazılı izin alındı. BYÖ ve OÖ için yazarlardan mail yoluyla izin alındı. Çalışmaya katılan ögrencilere çalışma konusunda bilgi verilip sözel olurları alındı. Yanıtlaması 15-20 dakika süren anket formu, araştırmacılar tarafindan öğrencilere verilerek gün içinde uygun oldukları zaman diliminde doldurmaları istendi. Doldurulan anket formlar1, günün sonunda araştırmacılar tarafından toplandı.

\section{Verilerin Değerlendirilmesi}

Çalışmadan elde edilen veriler IBM Corp. Released 2013. IBM SPSS Statistics for Windows, Version 22.0. Armonk, NY: IBM Corp. programı kullanılarak değerlendirildi. Kategorik değişkenler sayı ve yüzde; sürekli değişkenler ortalama ve standart sapma olarak verildi. Bağımsız iki gruba ait sıra ortalamaları karşılaştırılırken Mann WhitneyU testi, bağımsız ikiden fazla gruba ait sira ortalamaları karşılaştırılırken Kruskal Wallis analizi kullanıldı. Kruskal Wallis analizi sonunda, anlamlılık kararı verilmişse, farklılık yaratan grup ya da grupları bulabilmek için tekrar Bonferroni düzeltmeli Mann WhitneyU testi kulllanıldı. BYÖ ve OÖ alt boyutları arasındaki ilişkinin belirlenmesinde Spearman korelasyon analizi kullanıldı. Güvenilirlik analizi kullanılarak Croanbach's alfa değeri bulundu. Anlamlılık düzeyi $\alpha$ 0,05 olarak kabul edildi.

\section{Araştırmanın Sınırlılıkları}

Çalışmanın tek merkezli olması ve örneklem seçim yöntemine gidilmemiş olması elde edilen sonuçlarla genelleme yapılması mümkün değildir. Çalışma ile ilgili literatürün kısıtlı olması tartışmanın biçimlendirilmesini sinırlandırmaktadir.

\section{Bulgular}

Çalışmaya katılan öğrencilerin yaklaşık beşte ikisi, üçüncü sinıfta öğrenim görmekteydi (\%38.2). Yaş ortalaması 20.92 (SS:1.57) olup, 18-26 yaş aralığında değişmekteydi ve çoğunluğunu kız öğrenciler oluşturmaktaydı (\%93.6). Yarısından fazlası hemşireliği kendi kararı ile tercih ettiğini (\%51.6) ve büyük çoğunluğu lisans eğitimi sonrasında uzmanlaşmayı düşündüğünü (\%91.9) belirtti. Öğrencilerin üçte birinden fazlasının, hemşirelik lisans programlarının bakım verme (\%38.9) ve otonomi yeterliliğini (\%34.6) kazandırdığını, \%29.7'sinin ise yenilikçilik yeterliliğini kazandırmadığını düşündüğü görüldü. Yaklaşık üçte biri hemşirelik bakımı ile ilgili yenilikleri takip etmediğini ifade etti (\%33.6). Okul eğitiminin (\%74.2), internetin (\%67.8) ve klinik uygulama alanlarının (\%64.3) öğrencilerin yenilikler hakkında en fazla bilgi edindikleri üç kaynak olduğu saptand1. Öğrencilerin bireysel özellik ve yenilikçilikle ilgili görüşlerinin dağılımı Tablo 1'de gösterilmektedir.

Öğrencilerin BYÖ'nden aldıklar1 puan ortalamas1 $65.26 \pm 8.66$ (Min:48, Max:88) olup en yüksek puan ortalamasını fikir önderliği (26.28 44.23$)$, en düşük puan ortalamasını değişime direnç (19.22 \pm 5.17$)$ alt boyutlarından aldıkları görüldü. OÖ'nden aldıklar1 puan ortalamas1 $81.23 \pm 18.18$ (Min:26, Max:88) olup en yüksek puan ortalamasın1 özgürlük (34.90- \pm 7.71$)$, en düşük puan ortalamasını yalnızlıktan hoşlanma (14.70 \pm 5.13$)$ alt boyutlarından aldıkları görüldü (Tablo 2).

Öğrencilerin bireysel özellik ve yenilikçilik ile ilgili görüşleri ile BYÖ ve OÖ'den aldıkları sıra ortalamalarının karşılaştırılması Tablo 3'de verilmektedir. İkinci ve üçüncü sinıfta öğrenim gören öğrencilerin BYÖ'den aldıkları sıra ortalamas1, birinci sinıfta öğrenim gören öğrencilerden ileri düzeyde $(p<0.01)$ ve dördüncü sınıfta öğrenim gören öğrencilerden istatistiksel olarak anlamlı derecede $(p<0.05)$ yüksek bulundu. Dördüncü sınıfta öğrenim 
gören öğrencilerin OÖ’den aldıkları sira ortalamas1, birinci ve ikinci sınıfta öğrenim gören öğrencilerden istatistiksel olarak

Tablo 1. Öğrencilerin Bireysel Özellikleri ve Yenilikçilik ile İlgili Görüşleri (N=283)

\begin{tabular}{|c|c|c|}
\hline \multirow{2}{*}{\multicolumn{3}{|c|}{$\begin{array}{l}\text { Özellikler } \\
\text { Öğrenim Düzeyi }\end{array}$}} \\
\hline & & \\
\hline Birinci Sinıf & 56 & 19.7 \\
\hline İkinci Sınıf & 65 & 23.0 \\
\hline Ücüncü Sınıf & 108 & 38.2 \\
\hline Dördüncü Sınıf & 54 & 19.1 \\
\hline \multicolumn{3}{|l|}{ Yaş Grupları $(20.92 \pm 1.57)$} \\
\hline $18-20$ yaş & 117 & 41.3 \\
\hline $21-23$ yaş & 150 & 53.0 \\
\hline 24 yaş ve üzeri & 16 & 5.7 \\
\hline \multicolumn{3}{|l|}{ Cinsiyet } \\
\hline $\mathrm{K} 1 \mathrm{Z}$ & 265 & 93.6 \\
\hline Erkek & 18 & 6.4 \\
\hline \multicolumn{3}{|l|}{ Hemșireliği Tercih Etme Sebepleri* } \\
\hline Kendi kararım & 146 & 51.6 \\
\hline Garanti bir is & 106 & 37.5 \\
\hline Gelişmekte olan bir meslek & 54 & 19.1 \\
\hline Sevdiğim için & 53 & 18.7 \\
\hline Aylık geliri iyi & 45 & 15.9 \\
\hline Aile baskısı & 29 & 10.2 \\
\hline Hayalimdeki meslek & 21 & 7.4 \\
\hline Diğer & 18 & 6.4 \\
\hline
\end{tabular}

Hemşirelik Eğitimi Sonrası

Uzmanlaşma Düşüncesi

Düşünüyorum $\quad 260 \quad 91.9$

$\begin{array}{lll}\text { Düşünmüyorum } & 12 & 4.2\end{array}$

Kararsizım

$11 \quad 3.9$

Bakım Verme Yeterliliğini

$\begin{array}{lll}\text { Kazandırması } & 110 & 38.9\end{array}$

Olumlu düșünüyorum $\quad 92 \quad 32.5$

$\begin{array}{lll}\text { Olumsuz düşünüyorum } & 81 \quad 28.6\end{array}$

Kararsizım

\begin{tabular}{lcc}
\hline Otonomi Yeterliliğini Kazandırması & & \\
Olumlu düşünüyorum & 98 & 34.6 \\
Olumsuz düşünüyorum & 98 & 34.6 \\
Kararsızım & 87 & 30.7 \\
\hline Yenilikçilik Yeterliliğini & & \\
Kazandırması & & \\
Olumlu düşünüyorum & 95 & 33.6 \\
Olumsuz düşünüyorum & 84 & 29.7 \\
Kararsızım & 104 & 36.7 \\
\hline Bakımdaki Yenilikleri Takip Etmesi & & \\
Evet & 188 & 66.4 \\
Hayır & 98 & 33.6 \\
\hline Yenilikler Hakkındaki Bilgi & & \\
Kaynakları* & & \\
Okul eğitimi & 210 & 74.2 \\
İnternet & 192 & 67.8 \\
Uygulama Alanları & 182 & 64.3 \\
Kongre, konferans, seminer & 160 & 56.5 \\
Akademik yayınlar & 97 & 34.3 \\
Mesleki dernekler & 32 & 11.3 \\
Diğer & 10 & 3.5 \\
\hline \multicolumn{2}{c}{ *: Birden fazla seçeneğin işaretlendiği sorulardır } \\
\hline
\end{tabular}

anlamlı derecede düşük bulundu ( $\mathrm{p}<0.05) .24$ ve üzeri yaş grubunda olan öğrencilerin OÖ'nden aldıkları sıra ortalaması, 18-20 yaş ve 21-23 yaş grubunda olan öğrencilerden ileri düzeyde anlamlı derecede düşük bulundu $(p<0.01)$. Mesleği kendi kararları ile tercih edenlerin BYÖ'den aldıkları sira ortalaması, diğer sebeplerle tercih edenlerden istatistiksel olarak anlamlı derecede yüksek bulundu $(p<0.05)$. Lisans eğitimi sonras1 uzmanlaşmayı düşünen öğrencilerin BYÖ'den aldıkları sira ortalaması, düşünmeyen/kararsız kalanlardan istatistiksel olarak anlamlı derecede yüksek bulundu $(p<0.05)$. Hemşirelik eğitim programlarının yenilikçilik yeterliliğini kazandırdığını düşünmeyenlerin BYÖ'den aldıkları sira ortalaması, düşünen ve kararsız olan öğrencilerden ileri düzeyde anlamlı derecede yüksek bulundu $(\mathrm{p}<0.01)$. Hemşirelik bakımında yenilikleri takip eden öğrencilerin BYÖ'den aldıkları sira ortalaması, etmeyenlere göre çok ileri düzeyde anlamlı derecede yüksek bulundu $(\mathrm{p}<0.001)$. Öğrencilerin diğer bireysel özellikleri ve görüşleri ile BYÖ ve OÖ'den aldıkları sıra ortalamaları arasında istatistiksel olarak anlamlı farklılık bulunmadı ( $>0.05$ ).

Tablo 2. Öğrencilerin BYÖ ve OÖ ve Alt Boyutlarından Aldıkları Puan Ortalamaları (N=283)

\begin{tabular}{lcc}
\hline $\begin{array}{l}\text { Ölçekler ve Alt } \\
\text { Boyutları }\end{array}$ & Ort. \pm S.S. & $\begin{array}{c}\text { Min.- } \\
\text { Max. }\end{array}$ \\
\hline Fikir Önderliği & $26.28 \pm 4.23$ & $15-35$ \\
Değişime Direnç & $19.22 \pm 5.17$ & $7-34$ \\
Risk Alma & $16.20 \pm 2.60$ & $8-20$ \\
BYÖ & $65.26 \pm 8.66$ & $48-88$ \\
\hline Özgürlük & $34.90 \pm 7.71$ & $11-48$ \\
Kişisel Başarı & $31.63 \pm 7.53$ & $7-48$ \\
Yalnızlıktan & $14.70 \pm 5.13$ & $0-24$ \\
Hoşlanmama & $81.23 \pm 18.18$ & $26-120$ \\
OÖ & & \\
\hline
\end{tabular}

Öğrencilerin BYÖ ile OÖ'den aldıkları sıra ortalamaları arasında pozitif yönde zayıf ilişki saptandı $(\mathrm{r}=0.26 ; \mathrm{p}<0.001)$. OÖ ile BYÖ alt boyutları arasındaki ilişki Tablo 4'de verilmektedir. Öğrencilerin bireysel yenilikçilik davranışları sınıflandırıldığında, \%36.4'ünün kuşkucu kategorisinde ve \%4.2'sinin yenilikçi kategorisinde yer aldığ1 görüldü. Bireysel yenilikçilik davranışları ile OÖ’nden aldıkları sıra ortalamaları karşılaştıııldığında, yenilikçi aldıkları sıra ortalaması, diğer kategorilerde yer alan öğrencilerden çok ileri düzeyde anlamlı derecede yüksek bulundu $(\mathrm{p}<0.001)$. 
Tablo 3. Öğrencilerin Bireysel Özellikleri ve Yenilikçilik ile İlgili Görüşleri ile BYÖ ve OÖ’nden Aldıkları Sıra Ortalamalarının Karşılaştırılması ( $\mathrm{N}=283)$

\begin{tabular}{|c|c|c|c|c|}
\hline \multirow[b]{2}{*}{ Bireysel Özellik ve Görüşler } & \multicolumn{2}{|c|}{ BYÖ } & \multicolumn{2}{|c|}{ OÖ } \\
\hline & $\begin{array}{c}\text { Sira } \\
\text { Ortalamas1 }\end{array}$ & $\begin{array}{l}\text { Test ve } p \\
\text { Değeri }\end{array}$ & $\begin{array}{c}\text { Sira } \\
\text { Ortalamas1 }\end{array}$ & $\begin{array}{l}\text { Test ve p } \\
\text { Değeri }\end{array}$ \\
\hline \multicolumn{5}{|l|}{ Öğrenim Düzeyi } \\
\hline Birinci Sinıf ${ }^{a}$ & 107.83 & $\mathrm{KW}=17.332$ & 159.16 & $\mathrm{KW}=8.077$ \\
\hline İkinci Sinıf ${ }^{\mathrm{b}}$ & 157.45 & $\mathrm{p}=0.001$ & 152.62 & $\mathrm{p}=0.044$ \\
\hline Üçüncü Sınıf ${ }^{c}$ & 157.21 & $b, c>a, d$ & 138.24 & $\mathrm{~d}<\mathrm{a}, \mathrm{b}$ \\
\hline Dördüncü Sınıf $\mathrm{f}^{\mathrm{d}}$ & 128.43 & & 118.94 & \\
\hline \multicolumn{5}{|l|}{ Yaş Grupları } \\
\hline $18-20$ yaş $^{\mathrm{a}}$ & 136.44 & $K W=3.686$ & 148.45 & $\mathrm{KW}=6.037$ \\
\hline $21-23$ yaş $^{\mathrm{b}}$ & 149.37 & $\mathrm{p}=0.158$ & 141.99 & $\mathrm{p}=0.049$ \\
\hline 24 yaş ve üzeri $^{\mathrm{c}}$ & 113.62 & & 94.88 & $c<a, b$ \\
\hline \multicolumn{5}{|l|}{ Cinsiyet } \\
\hline $\mathrm{K} 1 \mathrm{Z}$ & 143.47 & $Z=-1.163$ & 140.21 & $Z=-1.411$ \\
\hline Erkek & 120.31 & $\mathrm{p}=0.245$ & 168.33 & $\mathrm{p}=0.158$ \\
\hline \multicolumn{5}{|l|}{ Hemşireliği Tercih Etme Sebepleri } \\
\hline Kendi kararı ile tercih edenler & 165.52 & $\mathrm{Z}=2.323$ & 139.51 & $Z=-1.066$ \\
\hline Farklı sebeplerle tercih edenler & 136.58 & $\mathrm{p}=0.02$ & 152.80 & $\mathrm{p}=0.286$ \\
\hline \multicolumn{5}{|l|}{ Eğitim Sonrası Uzmanlaşma } \\
\hline Düşünüyorum & 145.23 & $\mathrm{Z}=-2.233$ & 142.69 & $Z=-0.480$ \\
\hline Düşünmüyorum/Kararsızım & 105.50 & $\mathrm{P}=0.026$ & 134.15 & $\mathrm{p}=0.631$ \\
\hline \multicolumn{5}{|c|}{ Bakım Verme Yeterliliğini Kazandırması } \\
\hline Olumlu düşünüyorum & 145.66 & $\mathrm{KW}=2.718$ & 144.40 & $\mathrm{KW}=0.788$ \\
\hline Olumsuz düşünüyorum & 147.54 & $\mathrm{p}=0.337$ & 145.12 & $\mathrm{p}=0.674$ \\
\hline Kararsızım & 130.74 & & 135.20 & \\
\hline \multicolumn{5}{|c|}{ Otonomi Yeterliliğini Kazandırması } \\
\hline Olumlu düşünüyorum & 130.89 & $\mathrm{KW}=5.892$ & 139.75 & $\mathrm{KW}=1.105$ \\
\hline Olumsuz düşünüyorum & 157.90 & $\mathrm{p}=0.053$ & 148.84 & $\mathrm{p}=0.575$ \\
\hline Kararsızım & 136.61 & & 136.93 & \\
\hline \multicolumn{5}{|c|}{ Yenilikçilik Yeterliliğini Kazandırması } \\
\hline Olumlu düşünüyorum ${ }^{\mathrm{a}}$ & 131.64 & $\mathrm{KW}=14.083$ & 137.16 & $K W=3.059$ \\
\hline Olumsuz düşünüyorum ${ }^{b}$ & 170.02 & $\mathrm{p}=0.001$ & 155.07 & $\mathrm{p}=0.217$ \\
\hline Kararsizim $^{\mathrm{c}}$ & 128.84 & $\mathrm{~b}>\mathrm{a}, \mathrm{c}$ & 135.87 & \\
\hline \multicolumn{5}{|c|}{ Bakımdaki Yenilikleri Takip Etmesi } \\
\hline Evet & 156.35 & $Z=-4.153$ & 146.74 & $\mathrm{Z}=-1.371$ \\
\hline Hayır & 113.60 & $\mathrm{P}=0.000$ & 132.62 & $\mathrm{p}=0.170$ \\
\hline
\end{tabular}

KW: Kruskal Wallis Analizi, Z: Mann Whitney-U testi

Tablo 4. Öğrencilerin BYÖ ve OÖ’den Aldıkları Sıra Ortalamaları Arasındaki İlişki (N=283)

\begin{tabular}{|c|c|c|c|c|}
\hline Ölçek ve Alt Boyutları & $\begin{array}{c}\text { Fikir } \\
\text { Önderliği }\end{array}$ & $\begin{array}{l}\text { Değişime } \\
\text { Direnç }\end{array}$ & $\begin{array}{l}\text { Risk } \\
\text { Alma }\end{array}$ & BYÖ \\
\hline Kişisel Başarı & $0.37^{\mathrm{a}}$ & 0.08 & $0.32^{\mathrm{a}}$ & $0.20^{\mathrm{b}}$ \\
\hline Özgürlük & $0.39^{a}$ & -0.03 & $0.40^{\mathrm{a}}$ & $0.30^{\mathrm{a}}$ \\
\hline Yalnızlıktan Hoşlanma & $0.37^{\mathrm{a}}$ & 0.11 & $0.27^{\mathrm{a}}$ & $0.18^{b}$ \\
\hline OÖ & $0.42^{\mathrm{a}}$ & 0.05 & $0.37^{\mathrm{a}}$ & $0.26^{\mathrm{a}}$ \\
\hline
\end{tabular}


Tablo 5. Öğrencilerin Bireysel Yenilikçilik Davranışları ile OÖ’nden Aldıkları Sıra Ortalamalarının Karşılaştırılması (N=283)

\begin{tabular}{lcccc}
\hline $\begin{array}{l}\text { Bireysel Yenilikçilik } \\
\text { Davranışları }\end{array}$ & Sayı & Yüzde & Sıra Ortalaması & Test ve p Değeri \\
\hline Gelenekçi & 56 & 19.8 & 109.27 & \\
Kuşkucu & 103 & 36.4 & 137.72 & KW=25.957 \\
Sorgulayıcı & 79 & 27.9 & 142.61 & $\mathrm{p}=0.000$ \\
Öncü & 33 & 11.7 & 187.62 & \\
Yenilikçi & 12 & 4.2 & 201.96 & \\
\hline
\end{tabular}

KW: Kruskal Wallis testi

\section{Tartışma}

Çalışmada öğrencilerin çoğunluğunun bakımda yenilikleri takip ettiği ve yenilikler hakkındaki bilgiyi okul eğitiminden aldığ 1 saptanmasına karşın, sadece üçte birinin lisans programlarının yenilikçilik davranışını kazandırmada yeterli olduğunu bildirdiği görülmektedir. Başka bir deyişle öğrencilerin, lisans programlarının yenilikler hakkında bilgi birikimini arttırdığ 1 ancak yenilikçi olmaları, yeniliği başlatmaları ve sürdürmeleri konusunda kendilerine yeterlilik kazandırmadığı görüşünde olduğu söylenebilir. Hemşirelik eğitim programında yer alan geleneksel öğretim yöntemlerinin yanında, teorik ve uygulamanın entegrasyonunu hedef alan simülasyon uygulamaları, vaka veya proje temelli ögrenme gibi yaratıcı ve yenilikçi öğretim yöntemlerinin kullanılması ve deneyime dayalı öğrenme ortamlarının yaratılması öğrencilerin olumsuz algılarının azalmasını sağlayabilir. Aynı zamanda farklı öğretim yöntemlerinin, hemşirelik öğrencilerinin yenilikçilik ve yaratıcılık düzeyleri üzerine etkisini gösteren tanımlayıcı ve deneysel çalışmalara ihtiyaç vardır.

Literatürde, hemşirelik öğrencilerinin bireysel yenilikçilik davranışlarının belirlendiği herhangi bir çalışmaya rastlanmadığından, karşılaştırma farklı meslek adayları ya da profesyonelleri üzerinde konu ile ilgili çeşitli ölçekleri kullanan ulusal ve uluslararası çalışmalarla yapılmıştır. Hemşirelik öğrencilerinin orta düzeyde yenilikçi olmaları $(\mathrm{BYÖ}=65,26 \pm 8,66)$, ülkemizde BYÖ ile ögretmen adayları ve hemşireler üzerinde ve farklı bir ölçme aracı ile Kaliforniya'da hemşireler üzerinde yapılan çalışmalarla benzerlik göstermektedir. ${ }^{12-16}$ Yine aynı çalışmalarda öğretmen adaylarının en fazla sorgulayıcı kategoride yer aldığı görülürken, çalışmamızda hemşirelik öğrencileri en fazla kuşkucu kategorisinde yer almaktadır. Bu durumda öğretmen adaylarına göre hemşirelik öğrencilerinin ağırlıklı olarak yeniliklere karş1 çekingen ve şüpheci bir tavır sergiledikleri ve toplumun genelinin kabul etmesinin ardindan yenilikleri benimsedikleri, bir başka deyişle yeniliklere karşı daha temkinli bir tavır sergiledikleri söylenebilir. Diğer çalışmalarla karşılaştırıldığında, hemşirelik öğrencilerinin fikir önderliği ve risk alma puan ortalamalarının daha yüksek, değişime direnç puan ortalamasının ise daha düşük olduğu görülmektedir. ${ }^{12-15,17} \mathrm{Bu}$ duruma göre hemşirelik öğrencilerinin yenilikçi fikirlerini uygulamaya geçirmede daha cesur davrandığ 1 , çevresindekileri bu konuda daha fazla etkileme eğilimi gösterdiği ve değişime ve yeniliğe karşı daha az direnç gösterdiği sonucuna varılabilir.

Çalışmada öğrencilerin OÖ puan ortalamalarını 81,2 olması, otonomi düzeylerinin orta düzeyde yüksek olduğu anlamına gelmektedir ve ülkemizde OÖ ile yapılan diğer çalışmalarla benzerlik göstermektedir. Aynı çalışmalarla uyumlu olarak birinci sinıftaki öğrencilerin otonomi düzey-lerinin, dördüncü siniftakilerden daha yüksek olduğu görülmektedir. ${ }^{18-20}$ Çalışmada hemşirelik öğrencilerinin otonomi düzeylerinin, bireysel özellik ve görüşleri ile karşılaştırıldığında öğrenim düzeyi dolayısıyla yaş grupları dışında anlamlı farklılık yaratmaması ve yıllar içinde yapılan başka çalışmalarda da otonomi düzey-lerinde belirgin bir artış görülmemesi, öğrencilerin otonomilerini geliştirme konusunda hemşirelik eğitim programlarının eksikliklerinin ya da yetersizliklerinin olduğunu düşündü-rmektedir. Öğrencilerin yaklaşık üçte ikisinin, hemşirelik programlarının bakım verme ve otonomi kazandırma yeterliliği konusunda olumlu görüş belirtmemesi, bu düşünceyi destekler niteliktedir. Her geçen gün değişen ve gelişen sağlık bakım ortamlarında, hemşireliğin varlığını sürdürebilmesi için yeni rol ve beceriler geliştirmesinin yanı sıra hemşirelik eğitiminin de otonomi düzeyi 
yüksek meslek mensuplarını yetiştirmesi gereklidir. Literatür, hemşirelik öğrencilerinin otonomileri geliştirildiğinde, eleştirel düşünme becerilerini de arttıracağını bu nedenle öğrenim hedefleri kapsamına alınması gerektiğini belirtmektedir. ${ }^{21,22}$ Hemşirelik lisans programının ilk senesinden başlayarak profes-yonel role geçiş süreci de dahil olmak üzere meslek adaylarının otonomi düzeylerini arttıran ve mesleki yaşamına hazır hissettiren, öğrenci merkezli, yaparakyaşayarak öğrenme stratejilerinin geliştirilmesine ve eğitim planına entegre edilmesine ihtiyaç vardır.

Literatürde bireysel yenilikçilik davranış1 ile otonomi düzeyi arasındaki ilişkiyi irdeleyecek veriler kisitlı olmakla beraber, çalışmanın sonuçları öğrencilerin otonomik kişilik özellikleri arttıkça bireysel yenilikçilik davranışlarının da artacağını göstermektedir. Bu sebeple öğrenci merkezli ve öğrencinin aktif katılımını sağlayan öğretim yöntemlerinin kullanılmasının gerekliliği bir kez daha karşımıza çıkmaktadır. Bu noktadan hareketle, özellikle simülasyon gibi, güvenli bir öğrenme ortamında, öğrencilerin hata yapma korkusu yaşamadan kendi deneyimlerinden öğrenmelerine firsat sağlayan öğretim stratejilerinin kullanılması kaçınılmazdır. Bulgular doğrultusunda, geleceğin hemşirelerinin otonomik kişilik özelliklerinin baskın olması dolayısıyla bireysel yenilikçilik davranışlarının yüksek olması, hemşireliğin değişen ve gelişen sağlık ortamının nabzını tutabilmesi bakımından umut vericidir.

\section{Sonuç}

Hemşirelik öğrencilerinin bireysel yenilikçilik davranışları ile otonomi düzeyleri arasındaki ilişkiyi belirlemek amacıyla yapılan bu çalışmada öğrencilerin, bireysel yenilikçilik davranışı ve otonomi düzeylerinin orta derecede yüksek olduğu, en fazla kuşkucu kategorisinde yer aldığ 1 bununla beraber otonomi düzeyleri arttıkça bireysel yenilikçilik düzeylerinin de $\operatorname{arttığ1}$ saptandı. Elde edilen bulgular doğrultusunda, hemşirelik eğitim programlarına yaratıcılığa ve yenilikçiliğe teşvik eden ve otonomi düzeylerini geliştiren öğretim yöntemlerinin kullanılması, kullanılan farklı öğretim yöntemlerinin öğrencilerin bireysel yenilikçilik ve otonomi düzeylerine etkisini gösteren tanımlayıcı ve deneysel çalışmaların yapılması önerilmektedir.

\section{Teşekkür}

Verilerin toplanmasinda desteklerini esirgemeyen sevgili öğrencilerimiz, İpek Yazgan, Gamze Koçan,
Sevcan Yağc1, Beyza Nur Hayta ve Filiz Durmuş'a sonsuz teşekkür ederiz.

\section{Kaynaklar}

1- Kalisch BJ, Begeny S. Preparation of nursing students for change and innovation. West $\mathbf{J}$ Nurs Res 2010; 32(2): 157-167.

2- Kim SJ, Park M. Leadership, knowledge and creativity: the key factors in nurses' innovative behaviors. J Nurs Adm 2015; 45(12): 615-621.

3- Kara D. İnnovation in nursing practices. Global Journal on Advances in Pure\&Applied Sciences 2015; 7: 170-174.

4- Hughes F. Nurses at the forefront of innovation. Int Nurs Rev 2006; 53(2): 94101.

5- Chang L, Liu C. Employee empowerment, innovative behavior and job productivity of public health nurses: a cross-sectional questionnaire survey. Int J Nurs Stud 2008; 45 (10): 1442-8.

6- Lin CL, Wang YN, Tsai HM. Innovative thinking in nursing practice. $\mathrm{Hu} \mathrm{Li} \mathrm{Za} \mathrm{Zhi}$ 2013; 60(2): 97-102

7- Sönmez B, Yıldırım A. Bir üniversite hastanesinde çalışan hemşirelerin yenilikçi davranışları ve yenilikçi davranışlarını etkileyen faktörlere ilişkin görüşlerinin belirlenmesi: niteliksel bir çalışma. Sağlık ve Hemşirelik Yönetimi Dergisi 2014; 2(1): 4959.

8- Büyükbayram A, Arabacı LB, Taş G, Varol D. Öğrenci hemşirelerin duygusal zekâ ve sosyotropi-otonomi kişilik özellikleri ile psikolojik dayanıklılıkları arasındaki ilişki. İzmir Kâtip Çelebi Üniversitesi Sağl1k Bilimleri Fakültesi Dergisi 2016; 1(3): 2937.

9- Skar R. The meaning of autonomy in nursing Practice. J Clin Nurs 2009; 19: 2226-2234.

10- Sarığlu A. Bireysel yenilikçilik ölçeğinin hemşirelikte geçerlik ve güvenirliği. Atatürk Üniversitesi: Sağlı Bilimleri Enstitüsü, Yükseklisans Tezi. Erzurum: 2014.

11- Şahin N, Ulusoy N, Şahin N. Exploring the sociotropy-autonomy dimensions in a sample of Turkish psychiatric inpatients. J Clin Psychol 1993; 49: 751-763.

12- Çuhadar Ç, Bülbül T, Ilgaz G. Öğretmen adaylarının bireysel yenilikçilik özellikleri ike teknopedogojik eğitim yeterlilikleri arasındaki ilişki. İlköğretim Online 2013; 12 (3): 797-807. 
13- Özgür H. Bilişim teknolojileri öğretmen adaylarının eleştirel düşünme eğilimleri ile bireysel yenilikçilik özellikleri arasındaki ilişkinin çeşitli değişkenler açısından incelenmesi. Mersin Üniversitesi Eğitim Fakültesi Dergisi 2013; 9(2): 409-420.

14- Korucu AT, Olpak YZ. Öğretmen adaylarının bireysel yenilikçilik özelliklerinin farklı değişkenler açısından incelenmesi. Eğitim Teknolojisi Kuram ve Uygulama 2015; 5(1): 111-127.

15- Yiğit S, Aksoy K. A comparison between generation $\mathrm{X}$ and generation $\mathrm{Y}$ in terms of individual innovativeness behavior: the case of Turkish health professionals. Int $\mathrm{J}$ Bus Adm 2015; 6(2): 106-117.

16- Dy Bunplin JJ, Chapman S, Blegen M, Spetz J. Differences in innovative behavior among hospital-based registered nurses. J Nurs Adm 2016; 46 (3): 122-127.

17- Işı1k C, Türkmendağ T. Atatürk Üniversitesi turizm fakültesi öğrencilerinin bireysel yenilikçilik algılarının belirlenmesi. Turizm Fakültesi Dergisi 2016; 70-99.

18- Kaya N, Aştı T, Acaroğlu R, Kaya H, Şendir M. Hemşirelik öğrencilerinin sosyotropikotonomik kişilik özellikleri ve ilişkili faktörlerin incelenmesi. Cumhuriyet Üniversitesi Hemşirelik Yüksekokulu Dergisi 2006; 10(3): 1-11.

19- Karagözoğlu Ş. Nursing students level of autonomy: a study from Trukey. Nurs Educ Tod 2009; 29(2): 176-187.

20- Şenturan L, Köse S, Sabuncu N, Özhan F, Göktaş S. Nursıng students' of autonomy and submissive behaviours: four-year follow up. Anadolu Hemşirelik ve Sağlık Bilimleri Dergisi, 2016;19(3): 175-181.

21- Potter PA, Perry GA. Fundamentals of nursing: concepts, process, and practice. 4th ed. Missouri: Mosby Company; 2003. p. 31324.

22- Lewis FM, Sterling E. Autonomy in nursing. Ishikawa of Nursing 2006; 3: 1-5. 